\title{
Analysis of international competitive positioning of quality wine from Spain
}

\author{
Juan Sebastián Castillo and $\mathrm{M}^{\mathrm{a}}$ Carmen García \\ Instituto de Desarrollo Regional, Universidad Castilla-La Mancha, Campus Universitario s/n, Albacete, \\ Spain.
}

\begin{abstract}
J.S. Castillo, and M.C. García. 2013. Analysis of international competitive positioning of quality wine from Spain. Cien. Inv. Agr. 40(3):491-501. The global vitiviniculture sector is undergoing systemic and thorough changes. Spain occupies a privileged position in the global industry, ranking first in surface area, third in production and second in export volume. In recent years, domestic consumption has experienced a clear and pronounced decline, as observed in France and Italy. Therefore, exportation has become the main commercial avenue for table and quality wine. In Spain, designated quality wine represents $50 \%$ of total production and has experienced commercial dynamics in international markets that differ from those affecting table wine. The object of this paper is to analyze the factors influencing the competitiveness of quality wine, represented by designations of origin, in international markets. After defining a competitiveness index, adapted from the Balassa index, and using environmental and internal variables, three panel data models of the most representative Designations were specified for the $2000 / 2001$ to $2009 / 2010$ seasons. The results demonstrated that environmental variables were more influential in explaining the weak international competitive positioning of the poorer performing Designations. European regulations resulting from the Common Agricultural Policy (CAP) and the economic crisis were significant and influential in this respect. Economies of scale, quality, and unit cost were the most influential internal factors for each D.O.factors for the most competitive quality-wine production areas.
\end{abstract}

Key words: Agricultural economics, competitiveness, designation of origin, foreign trade, panel data, quality wine.

\section{Introduction}

Analyzing quality wine implies assessing what such an abstract concept means. In the case of Spain, this designation is determined by the territorial origin of the wine, along the lines of terroir in the French tradition. Maher (2001),

Received March 29, 2013. Accepted September 25, 2013. Corresponding author: sebastian.castillo@uclm.es
Bouamra-Mechemache and Chaaban (2010), Deselnicu et al. (2011), and Valenciano and Roman (2011) agree that quality is a means of product differentiation. In Spain, the fertility and variety of the soil and the climate have favored the presence of a number of wines, each with a characteristic personality (Jones and Davis, 2000). Therefore, an important number of Designations of Origin (D.O.s) were recognized as a product identification 
mark (Thode and Maskulka, 1998; Ribeiro et al., 2002; Martínez-Carrasco et al., 2005).

D.O.s represented 50\% of Spanish vitiviniculture production in the $2010 / 2011$ season, near the standards of the other two great global wine producers, France and Italy. At the international level, exports increased by $32 \%$ over the past decade (Figure 1). The Cava, Rioja, Valencia and La Mancha D.O.s stand out with over $50 \%$ of the market quota (Figure 2). The EU is the main destination for exports, receiving $71 \%$, followed by the USA with $9 \%$ and, in recent years, China with $2 \%$ (Figure 3).

These initial data show the clear dynamism of quality wine exports that, according to Markusen (1992), indicates an increase in competitiveness. For the purposes of this article, competitiveness is understood in Markusen's terms, defined as an industry's increasing market share of exports to a specific market. As Balassa (1965), Araoz (1998) and Roldan (2000) indicate, increased competitiveness reflects ongoing efforts to acquire differentiating attributes and gain advantages. Therefore, the objective of this paper is to measure that notion of competitiveness in Markusen's terms (1992) and study its determinants.

An index adapted from that developed by Balassa was employed to measure competitiveness, a concept that has been used by researchers such as Van Rooyen et al. (2000), Valentine and Krasnik (2000), Pitts et al. (2001) and Esterhuizen (2005) to examine the South African wine industry. Boriraj (2008) applied it to the Australian wine industry; Cerda et al. (2008) used it to study the competitiveness of Chilean wine exports; Medina and Martínez (2012) applied it to the main exporting countries (France, Italy, Spain, Portugal, Germany, Argentina, Australia, Chile, the USA, and South Africa), and Martínez and Medina (2013) used it to analyze the Spanish wine sector.

This paper also calculated a competitiveness index, adapted from the Balassa index and formulated as ${ }^{I C_{D O}}=\frac{x_{D O, j} / \sum_{j=1}^{N} X_{D D, j}}{C_{D D, j} / \sum_{j=1}^{N} c_{D O, j}}$ where $X_{D O, j}$ represents exports; $C_{D O, j}$, total trade; and $N$, total D.O.s $(\mathrm{i}=1, \ldots \mathrm{j})$. The mean $\mathrm{IC}_{\mathrm{DO}}$ was 0.65 over the past decade, with a rising trend exhibited throughout the period, increasing more due to the increased share exported to international markets than with the interior market (Figure 4). However, the growth in international trade has not been homogeneous. There are outstanding differences among D.O.s in the $\mathrm{IC}_{\mathrm{DO}}$ (Figure 5).

Having defined competitiveness, it is necessary to analyze the factors that influenced the competitive international positioning of different D.O. areas. From the emergence of the discipline, the topic of commercial positioning has concerned international trade researchers. In a more recent, brief and superficial revision, Porter (1985) noted that low costs and product differentiation allow an organization to achieve a competitive advantage. For Mathison et al. (2007) and Gwynne (2008), the degree of innovation was responsible for competitive advantage. Rumelt (1991), Roquebert et al. (1996), and Mauri and Michaels (1998) argued that the talent and ability to acquire and manage resources explained competitive advantage, while Clifford and Cavanagh (1985) advocated the existing history and culture of the product. However, Aragón and Rubio (2005) stated that the capacity to achieve market success reflects a combination of factors: financial capacity, technological position, innovation, good marketing, human resources and information and communications technology (ICT).

This paper is more in line with the approach advocated by Moreira et al. (2011) that the current wine supply increases competition and there are many, diverse factors determining the level of competitiveness of an organization. In this paper, factors were grouped into two categories: 1) environmental factors affecting all Designations, and 2) internal factors specific to each D.O. The first group includes the effects of the economic since 2007 and the reform of the Common Market Organisation (CMO) in 2008, 
two incidents from the first decade of the 2000s that affected the sector. Internal factors include: a) economies of scale, b) product differentiation, c) export destinations and d) price.

The theory and conceptual framework on which this research is based begins with economies of scale, the implications of which for international trade are due to seminal contributions by Porter (1985). Previous papers considering economies of scale as an explanatory factor for competitiveness in the wine sector include Esterhuizen and Van Rooyen (2006) for the South African wine industry, Skorpikova (2002) for wine from the Check Republic and Martin and Heien (2004) for the Californian wine industry. These researchers, together with Reinert (1995), Eyler (2001) and Rebelo et al. (2007), indicate that economies of scale have a positive effect on export competiveness. In addition to Porter (1985), Krugman (1989) also emphasized that economies of scale must be considered as a factor affecting trade imbalances: "introducing economies of scale as a determinant of trade seemed to resolve the puzzles uncovered by empirical work."

Porter (1985) and Oster (1999) consider product differentiation as a positive factor in an environment characterized by intense competitive rivalry. Therefore, producers should search for goods and services that are differentiated in terms of variety and/or quality to meet consumer demand (Martínez-Sandoval, 2005). Product differentiation is significant in explaining competitiveness in Australian wine (Eyler, 2001), Californian wine (Gilinsky et al., 2006) and wine from the United States (Canning and Perez, 2008).

Export destinations are an important factor when studying competitiveness because, as Myro (2012) notes, a substantial increase in exports entails an increase in competitiveness.

The final variable considered is the price required by the theories of comparative advantage. In this traditional approach, the export prices of a country determine competitiveness in the market (Avondet and Pinero, 2007). Cancino del Castillo (2004) highlighted that in an analysis of export competitiveness, price must be considered, as prices and export shares move together. Medina and Martínez (2012) consider price in the Spanish context, while Bozsik (2005) does so for Hungarian wine on the international market; Cerda et al. (2008) use price to analyze the determinants of the competitiveness of Chilean wine exports, Vlahovic et al. (2009) does so for the wine industry in the Republic of Serbia and Van Rooyen et al. (2011) apply it to the South African wine industry. These authors find that a lower price is associated with increased competitiveness.

Although all of these variables are important when studying competitiveness, Schumpeter (1942) established that they should be considered jointly. Schumpeterian thinking advocates a wider perspective on the modus operandi for obtaining a dominant position in international markets, where quality competition, product differentiation, innovation in new markets and sales efforts are jointly considered with the traditional price variable.

In our case, following this central idea, we developed a model in which the competitiveness (according to Markusen, 1992) of Spanish quality wine was explained through Schumpeterian thinking using the above-mentioned factors. Our aim was to discover the most significant factors explaining the competitive positioning of D.O.s and the effectiveness of their positioning strategies in the international market.

\section{Materials and methods}

This study considered Spanish D.O.s representative of the period from 2000 to 2010 that had complete information available according to the reports edited by the Ministerio de Agricultura, Alimentación y Medio Ambiente. A balanced panel was formed with 38 production areas and 
10 seasons. The sample was representative of the population with an estimation error of 0.13 , for a confidence level of $95 \%$, after applying the formula $n=\frac{z^{2} \times p \times(1-p) \times N}{(N-1) \times e^{2}+Z^{2} \times p \times(1-p)}$, corresponding to a finite sample size.

The micro-econometric technique of Panel Data Modeling and associated tests were used to obtain the results. The independent variables included in the Panel Data Model were: 1) economies of scale (represented by surface area and the number of wineries), 2) product differentiation (symbolized by type of wine, type of bottle and a quality index), 3) export destination and 4) the price of bottled wine. Finally, two dichotomous variables were included: one to capture the effect of the crisis and the other to capture the change in European regulation affecting the sector, made in 2008 , which we call the CMO 2008 effect.

The dependent variable represents the competitiveness of D.O. wine in foreign markets

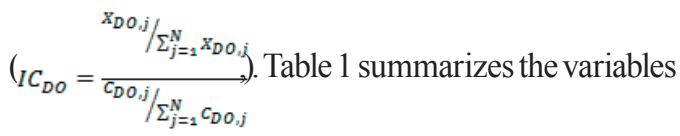
used, the units in which they are expressed, the statistical source from which they were obtained and their denotation in the model.

Before proceeding to the model specification, we applied the Equality Test by Classification; it revealed different reactions and behaviors among D.O.s. Therefore, three Balanced Panel Data Models were specified. The first (1) is a general model, including all D.O.s in the sample $(i=38$, $t=10$ ), independent of the $\mathrm{IC}_{\mathrm{Do}}$ value.

$I C_{D o, i t}=\beta_{0}+\sum_{k=1}^{12} \beta_{k} X_{k, i t}+\sum_{f=1}^{2} \delta_{f} F_{f, i t}+u_{i t}$

The second (2) is a model centered on competitive D.O.s abroad, that is, those with an $\mathrm{IC}_{\mathrm{DO}} \geq 1$, $(i=14, t=10)$.

$I C_{D o, i t}=\beta_{0}+\sum_{k=1}^{12} \beta_{k} X_{k, i t}+\sum_{f=1}^{2} \delta_{f} F_{f, i t}+u_{i t}$ with $I C_{D O, i t} \geq 1$

The third (3) includes the Designations of Origin that had an index value lower than one, $I C_{D O}<1$, $(i=24, t=10)$. The analytical equation for each is:

$I C_{D o, i t}=\beta_{0}+\sum_{k=1}^{12} \beta_{k} X_{k, i t}+\sum_{f=1}^{2} \delta_{f} F_{f, i t}+u_{i t}$

with $I C_{D O, i t}<1$

In equations (1), (2) and (3), $I C_{D O}$ is a linear equation of the $Q=14$ explanatory variables $(i=1, \ldots, N$ units and $t=1, \ldots, T$ observations over time). The error term, $u_{i t}$, follows a normal distribution with $E\left(u_{i}\right)$ $=0$ and $\operatorname{Var}\left(u_{i}\right)=\sigma^{2}$. In the Panel Data models, the structure of $u_{i t}$ comprises three components:

$u_{i t}=\alpha_{i}+\varnothing_{t}+\varepsilon_{i t}$

where $\alpha$ is the individual component, constant over time; $\Phi$ is the temporal component, constant across individuals; and $\varepsilon_{i t}$ is the random component representing the effect of all other variables that change across individuals and over time.

The models were specified using the cross-sectional, fixed effects method, and hence equation (4) becomes:

$$
u_{i t}=\alpha_{i}+\varepsilon_{i t}
$$

with $\alpha_{i}=\sum_{i=1}^{N-1} \alpha_{i} d_{i}$

Following this estimation, tests of significance and basic hypothesis tests were performed for validation purposes and subsequent economic interpretation.

\section{Results and discussion}

The Equality Test by Classification on the $I C_{D O, i}$ variable yielded a $p$-value below 0.05 for the ANOVA F-statistic $(\mathrm{P}=0)$ and the Levene 
Table 1. Description of variables.

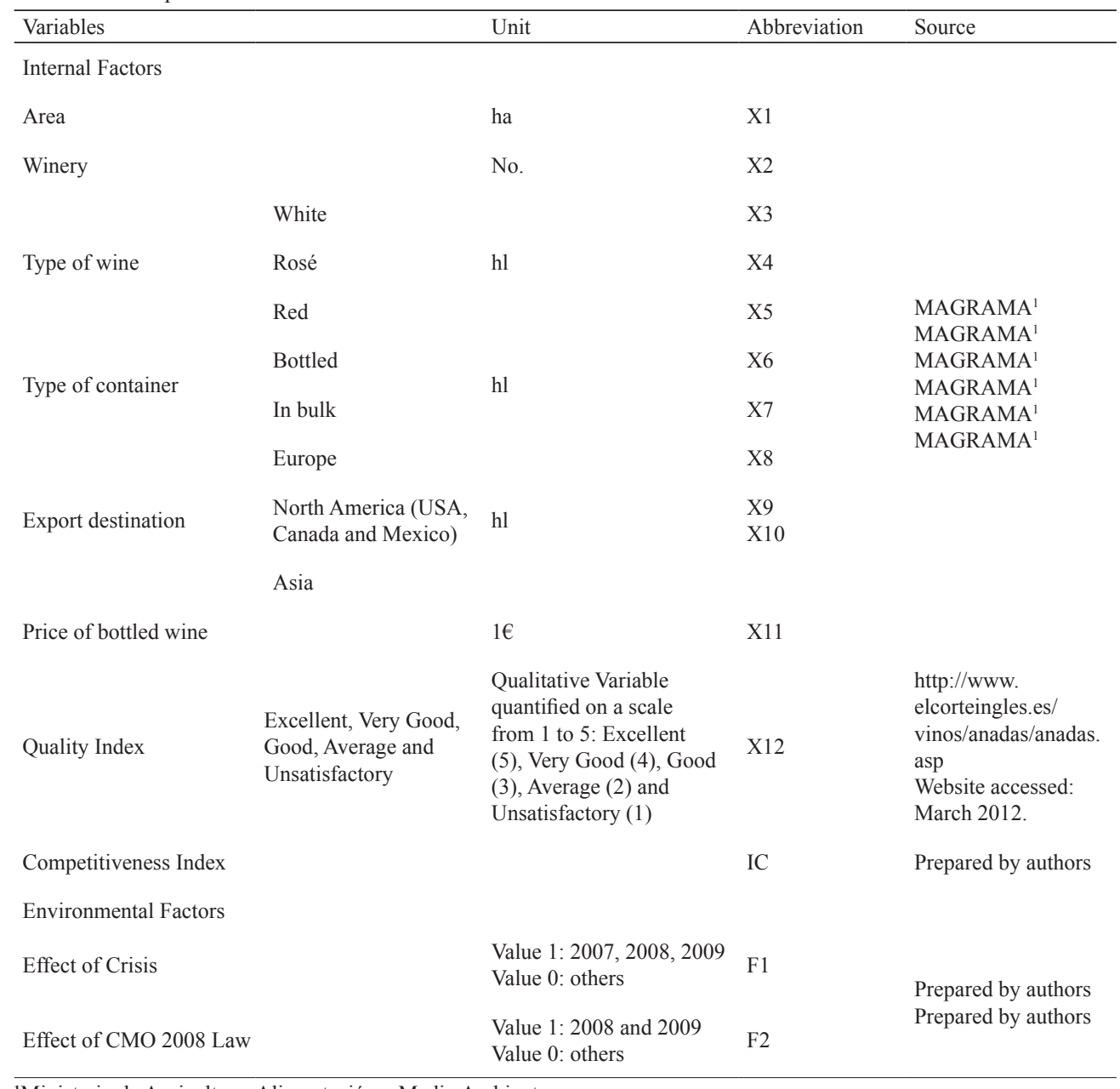

${ }^{1}$ Ministerio de Agricultura, Alimentación y Medio Ambiente.

$$
\begin{aligned}
\widetilde{I} \bar{C}_{D O, i t}=0.44 & +1.34 e-5 X_{1}+0.003 X_{2}-7.51 \mathrm{e}-6 X_{3}-5.25 \mathrm{e}-6 X_{4}-1.19 \mathrm{e} \\
& -5 X_{5}+1.15 \mathrm{e}-5 X_{6}+1.08 \mathrm{e}-5 X_{7}+1.65 \mathrm{e}-6 X_{8}+6.83 \mathrm{e} \\
& -7 X_{9}-6.53 \mathrm{e}-6 X_{10}-0.0003 X_{11}+0.0222 X_{12}+0.0046 F_{1} \\
& +0.092 F_{2}+[\mathrm{CX}=\mathrm{F}]
\end{aligned}
$$

$$
\begin{aligned}
\widetilde{I} \bar{C}_{D O, i t}=0.18 & +2.49 e-5 X_{1}-0.0017 X_{2}+4.57 \mathrm{e}-6 X_{3}+2.99 \mathrm{e}-6 X_{4}+5.73 \mathrm{e} \\
& -8 X_{5}+3.84 \mathrm{e}-6 X_{6}+4.05 \mathrm{e}-6 X_{7}-3,79 \mathrm{e}-6 X_{8}+5.32 \mathrm{e}-6 X_{9} \\
& -5.83 \mathrm{e}-6 X_{10}+0.0002 X_{11}+0.0595 X_{12}-0.0024 F_{1}-0.0279 F_{2} \\
& +[\mathrm{CX}=\mathrm{F}]
\end{aligned}
$$

$$
\begin{aligned}
& \widetilde{I} \bar{C}_{D O, i t}=0.7359-3.91 e-5 X_{1}+0,0003 X_{2}-2,99 \mathrm{e}-6 X_{3}-8.09 \mathrm{e}-6 X_{4}-1.90 \mathrm{e} \\
&-5 X_{5}+1.39 \mathrm{e}-5 X_{6}+6.71 \mathrm{e}-8 X_{7}+9.04 \mathrm{e}-6 X_{8}-5.82 \mathrm{e}-6 X_{9} \\
&-2.33 \mathrm{e}-5 X_{10}-0.0004 X_{11}-0.0005 X_{12}-0.0375 F_{1}+0.17 F_{2} \\
&+[\mathrm{CX}=\mathrm{F}]
\end{aligned}
$$


$(\mathrm{P}=0.0016)$ and the Brown-Forsythe $(\mathrm{P}=0.0010)$ tests. This means that Spanish D.O.s exhibit different behaviors. Consequently, all three models, (1), (2), and (3), were employed in the estimation to obtain general and particular conclusions on competitiveness.

The parameters of equations (1), (2) and (3), when estimated using Eviews 6.0. econometric software, became equations (6), (7) and (8), respectively.

The estimated equations, (6), (7) and (8), do not exhibit heteroscedasticity, as they were corrected using the White Cross-section method. They also do not exhibit autocorrelation according to the Durbin-Watson test, having values close to 2 . The F-Snedecor statistic, with an associated p-value of 0 , indicated significant models with a $100 \%$ probability in the set of independent variables. Regarding individual analysis of the variables for the general model (6), the t-Student statistic, at 95\% confidence, was significant: surface area and the number of wineries (economies of scale), price of wine, quality index (product differentiation) and the CMO 2008 effect. The same test for the second model (7) yields the following significant variables: surface area and the number of wineries (economies of scale) and the quality index (product differentiation). For the third model (8), they were: the price of bottled wine, the $\mathrm{CMO}$ effect and the impact of the crisis. Table 2 summarizes the results from each panel.

In summary, the models were econometrically and statistically valid, and ideal for use in the economic analysis.

The results indicate that Spanish quality wines with a territorial reference (D.O.s) focused their competitive positioning strategy on three aspects. The first was to produce low-cost wine, thus achieving important reductions in unit costs, as reflected in the traditional approach to comparative advantage. The second was a distinctive policy of segmenting with respect to quality and maintaining high standards without affecting costs through aggressive investments on innovation (Schumpeter and Porter's product differentiation). The third were economies of scale, which were decisive due to the large number of wineries with a large surface area (Krugman, 1989; Porter, 1985).

As open systems, their environment also conditioned their strategies: the changes in European regulation and the direct effect of the current economic crisis. The choice of destination markets was not a relevant strategy. The following represent important aspects of competitive strategy in the Spanish wine sector:

Table 2. Panel data results.

\begin{tabular}{lccc}
\hline & Model 1 & Model 2 & Model 3 \\
\hline Prob (F-statistic) & $\mathrm{P}=0^{*}$ & $\mathrm{P}=0^{*}$ & $\mathrm{P}=0^{*}$ \\
R-squared & 0.88 & 0.63 & 0.8 \\
Durbin-Watson & 1.67 & 1.8 & 1.7 \\
Prob (t-Student) & $\mathrm{P}=0.002^{* *}$ & $\mathrm{P}=0^{* *}$ & $\mathrm{P}=0.23$ \\
Area & & & \\
Winery & $\mathrm{P}=0.0747^{*}$ & $\mathrm{P}=0.007^{* *}$ & $\mathrm{P}=0.20$ \\
Price & $\mathrm{P}=0.0174^{*}$ & $\mathrm{P}=0.69$ & $\mathrm{P}=0.0046^{* *}$ \\
Quality Index & $\mathrm{P}=0 * *$ & $\mathrm{P}=0.0096^{* *}$ & $\mathrm{P}=0.97$ \\
Crisis & $\mathrm{P}=0.87$ & $\mathrm{P}=0.97$ & $\mathrm{P}=0.08^{*}$ \\
CMO 2008 & $\mathrm{P}=0 * *$ & $\mathrm{P}=0.28$ & $\mathrm{P}=0$ \\
\hline
\end{tabular}

**Significant at $1 \%$.

*Significant at $5 \%$. 
a) The presence and significance of economies of scale was a decisive factor determining the strategy of supporting quality maintenance without marginal cost increases, as Porter (1985) and Krugman (1989) indicate and demonstrated in recent papers by Skorpikova (2002) for wine from the Czech Republic, Martin and Heien (2004) for the California wine industry, Castaldi et al. (2006) in an analysis of competitiveness of the wine industry in general, and Kassier et al. (2008) for the South African wine industry. Economies of scale were significant in the dynamics of economic growth, but our results also extend this confirmation of significance to periods of economic recession, where the need to contain unit costs is decisive. We found that economies of scale were more significant in the more competitive D.O.s, which are the most extensive and have larger companies and a greater volume of commercialized wine.

b) In addition to competitiveness in substantial trade volumes, holding a strong competitive position with respect to price is particularly important. The results demonstrate that price is not as significant for the most competitive D.O.s, as it is for D.O.s that began to participate in international trade more recently. This indicates that providing high quality while containing prices is the primary positioning strategy for Spanish quality wine in foreign markets. Medina and Martínez (2012) also observed this correlation in the Spanish context. In the international context, Bozsik (2005) observed this result for Hungarian wine, Vlahović et al. (2009) for the wine industry in the Republic of Serbia, and Van Rooyen et al. (2011) did so for the wine industry in South Africa.

c) As mentioned above, the quality variable was a determinant of competitiveness, both during periods of economic expansion and recessions. The same results have been observed in the quality wine markets of Italy (Begalli et al., 2008) and France (Crozet et al., 2011). Quality affects the most competitive D.O.s to a greater extent, which is a consequence of their more sustained presence in the international market (Bernet and Stricker, 2003; Mueller et al., 2003). In the Spanish case, it must also be emphasized that this support for quality differentiation had to be combined with cost containment and, therefore, maintaining low final prices.

Of the environmental factors, the CAP reform of the sector, implemented by the Common Market Organization for wine and approved in 2008, positively influenced international D.O. competitiveness. The impact was more significant among D.O.s with lower competitive index scores. This is in line with one of the objectives of the new CMO, namely liberalization and increased competitiveness for European wine producers.

The elimination of public intervention in the markets that required distillation and subsidies to promote wine consumption in third world countries, widely taken advantage of by Spain, France and Italy, promoted the use of international commercial channels.

Finally, the economic crisis also had a decisive influence on the competitive position of quality wine. Rabobank (2010), analyzing the British wine industry and Larreina (2011), who considered the Rioja D.O, reached the same conclusion. However, the effect was smaller than in other non-quality products (González and Blanco, 2010; Valenciano and Román, 2011). In the case of Spain, this effect was particularly evident in the case of bulk table wine, which has made Spain the world leader for this type of wine. Moreover, the more affected D.O.s are those with lower competitiveness index scores. This explains why their sales are concentrated on the interior market. Therefore, they cannot diversify their business risk across a broader set of market segments or make aggressive investments to enter narrower segments.

In conclusion, in a globalized and competitive world, the search for foreign markets is no longer an option, but rather a necessity for 
quality wine from Designations of Origin as a guarantee of future growth. Consequently, internationalization is defined not only by the mere fact of exporting but also by the obligation to be competitive. The most influential factors of such competitiveness are economies of scale, product differentiation and price, along the lines of positioning defended by Schumpeter (1942), Porter (1985) and Krugman (1989).

\section{Acknowledgements}

The authors acknowledge the financing for this research by the PPII10-0158-0569 Regional Project, financed with the European Union ERDF Funds.

\title{
Resumen
}

\begin{abstract}
J.S. Castillo y M.C. García. 2013. Análisis del posicionamiento internacional competitivo de los vinos de calidad de España. Cien. Inv. Agr. 40(3): 491-501. El sector vitivinícola mundial está inmerso en una profunda y sistémica dinámica de cambios. España, ocupa una posición privilegiada en la escena global, primera posición en el ranking por superficie, tercera en producción y segunda en volumen exportado. El consumo interno, al igual que en los casos de Francia e Italia, ha experimentado un claro y nítido retroceso en los últimos años, con lo que las exportaciones se han configurado como la principal salida comercial para los vinos de calidad y los vinos de mesa. En España, los denominados vinos de calidad representan el $50 \%$ de la producción, y han experimentado una dinámica comercial diferenciada respecto a los vinos de mesa en los mercados internacionales. El objetivo de este estudio es analizar los factores que inciden en la competitividad en el mercado internacional de los vinos de calidad, representados por las Denominaciones de Origen. Para ello, tras definir un índice de competitividad, adaptado del índice de Balassa, y con variables de entorno e internas se especificaron tres modelos de datos de panel para las campañas 2000/2001 a 2009/2010 de las Denominaciones más representativas. Los resultados mostraron que las variables de entorno fueron más determinantes para entender el débil posicionamiento competitivo internacional de las Denominaciones más rezagadas. La regulación pública europea de la Política Agraria Común (PAC) y la crisis económica resultaron significativas y explicativas a este respecto. De los factores internos, las economías de escala, la calidad y el precio unitario salieron las más determinantes, para las zonas de producción de vino de calidad más competitivas.
\end{abstract}

Palabras clave: Economía agrícola, competitividad, denominación de origen comercio exterior, datos de panel, vino de calidad.

\section{References}

Aragón, A. and A. Rubio. 2005. Factores asociados con el éxito competitivo de las pyme industriales en España. Universia Business Review 8: 38-51.

Araoz, M. 1998. La Integración como instrumento para incrementar la Competitividad en un mundo globalizado: perspectivas en la Comunidad Andina. CEFIR, Montevideo. 8 pp.

Avondet, L. and F. Piñero. 2007. Comercio internacional y competitividad en la sociedad del conocimiento. Revista Digital de Contribuciones a la Economía. Available online at: http://www.eumed.net/ce/ (Website accessed: september 2, 2013). 
Balassa, B. 1965. Trade liberalization and revealed comparative advantage. The Manchester School of Economics and Social Studies 33: 99-123.

Begalli, D., S. Codurri, and D. Gaeta. 2008. Wine and web marketing strategies: the case study of Italian specialty wineries. 4th International Conference of the Academy of Wine Business Research. Siena, Italia. $19 \mathrm{pp}$.

Bernet, A., and S. Stricker. 2003. German wineries on the web: A survey of web sites of MoselSaar-Ruwer and Pfalz wineries. Wine Marketing Colloquium. Adelaide, Australia. Available online at: http://www.wine-economics.de/ Research/wineries.PDF (Website accessed: March 15, 2012).

Boriraj, J. 2008. Analysing and Modelling International Trade Patterns of the Australian Wine Industry in the World Wine Market. PhD thesis, Victoria University, Australia. 333 pp.

Bouamra-Mechemache, Z. and J. Chaaban. 2010. Determinants of adoption of protected designation of origin label: Evidence from the French brie cheese industry. Journal of Agricultural Economics 61: 225-239.

Bozsik, N. 2005. The price competitiveness of Hungarian wines in European Union markets. Scientific Journal on Agricultural Economics 49: 78-84.

Cancino del Castillo, C. 2004. Efectos del desarrollo tecnológico en el comercio exterior. Contabilidad y Sistemas 1(3), Universidad de Chile. Available online at: www.tecnogestion.cl/.../stories/newsletter/200607/articulos/ la_tecnologia al_servicio_del_comercio_exterior.pdf (Website accessed: September 5, 2013).

Canning, P., and A. Perez. 2008. Economic geography of the U.S. wine industry. American Association of Wine Economists 22: 1-36.

Castaldi, R., S. Cholette, and M. Hussain. 2006. A country-level analysis of competitive advantage in the wine industry. DEIAgra Working Papers 2: 15-27.

Cerda A., M. Alvarado, L. García, and M. Aguirre. 2008. Determinantes de la competitividad de las exportaciones de vino chileno. Panorama Socioeconómico 26: 172-181.
Clifford, D.K. and R.E. Cavanagh. 1985. The Winning Performance: How America's High-Growth Midsize Companies Succeed. Bantam Books. New York, United States. 292 pp.

Crozet M., K. Head, and T. Mayer. 2011. Quality sorting and trade: Firm-level evidence for French wine. The Review of Economic Studies 79: 609644.

Deselnicu O., M. Costanigro, D. Souza-Monteiro, and D. Thilmany. 2011. A Meta-Analysis of Geographical Indication Food Valuation Studies. What Drives the Premium for Origin Based Labels? American Association of Wine Economists 93:29.

Esterhuizen, D. 2005. An inquiry into the competitiveness of the South African agribusiness sector. $\mathrm{PhD}$ thesis, University of Pretoria. Pretoria, South Africa. 345 pp.

Esterhuizen, D., and V. Van Rooyen. 2006. An inquiry into the competitiveness of the South African wine industry. 16th Annual World Food and Agribusiness Forum and Symposium. International Food and Agribusiness Association. June 10-13, Argentina.

Eyler, R. 2001. Competing in the US wine market: Australian imports and tasting scores. International Journal of Wine Marketing 13: 32-42.

Gilinsky, A., R. Eyler, A. Casas, and E. Subirá, 2006. Challenge and change: an exploratory study of competitive strategy in the Northern California and Spanish wine industries. $3^{\circ}$ International Wine Business Research Conference, Montpellier, 6-7-8 July. Refereed Paper. 15 pp.

González, J., and A. Blanco Estévez. 2010. La competitividad exterior de la economía española. Boletín ICE 2983: 29-43.

Gwynne, R. 2008. Firm creation, firm evolution and clusters in Chile's dynamic wine sector: evidence from the Colchagua and Casablanca regions. American Association of Wine Economists 20. Available online at: http://www.wineeconomics. org/ workingpapers/ (Website accessed: November 5, 2012).

Jones, G.V., and R.E. Davis. 2000. Climate influences on grapevine phenology, grape composition, and wine production and quality for Bordeaux, 
France. American Journal of Viticulture and Enology 51: 249-261.

Kassier, E., N. Vink, M. Cherry, G. Wyk, S. Hobson, N. Sefoko, and J. Rooyen. 2008. South African wine industry benchmarking. Department of Agricultural Economics, Extension and Rural Development, University of Pretoria, South Africa. $84 \mathrm{pp}$.

Krugman, P. 1989. Industrial Organization and International Trade. In: Schmalensee, R. and Willing, R. (eds.). Handbook of Industrial Organization (Vol. II), North-Holland, Amsterdam. p. 1179 1223.

Larreina, M. 2011. El vino Rioja, ¿un modelo de éxito sostenible en el futuro? Cuadernos de Estudios Agroalimentarios 2: 11-27.

Maher, M. 2001. On vino Veritas - clarifying the use of geographic references on American wine labels. California Law Review 89: 1881-1924.

Markusen, J. 1992. Productivity, Competitiveness, Trade Performance and Real Income: The Nexus Among Four Concepts. Ottawa, Supply and Services Canada. 155 pp.

Martin, P., and D. Heien. 2004. The California Wine Industry: Entering a new era? Agricultural and Resource Economics 7: 5-8.

Martínez-Carrasco, L., M. Brugarolas, and A. Martínez-Poveda. 2005. Quality wines and wines protected by a designation of origin: Identifying their consumption determinants. Journal of Wine Research 16: 213-232.

Martínez-Sandoval, A. 2005. La diferenciación de productos: Una breve nota. Entramado 1: 34-47.

Martínez J.M., and F.J. Medina. 2013. La competitividad internacional de la industria vinícola española durante la globalización del vino. Revista de Historia Industrial 52: 139-174.

Mathison, L., J. Gándara, C. Primera, and L. García. 2007. Innovación: factor clave para lograr ventajas competitivas. Revista NEGOTIUM / Ciencias Gerenciales 7: 65-83.

Mauri, A., and M. Michaels. 1998. Firm and Industry effects within strategic management: an empirical examination. Strategic Management Journal 19: 211-219.
Medina, F.J., and J.M Martínez. 2012. La competitividad de las exportaciones de vino español y el mercado mundial 1960-2011. UHE Working Paper 03. Universidad Autónoma de Barcelona. 23 pp. Available online at: http://www.h-economica.uab.es/wps/2012_03.pdf (Website accessed: June 8, 2012).

Moreira V.H., J.L. Troncoso, and B.E. Bravo-Ureta. 2011. Eficiencia técnica de una muestra de productores chilenos de uva vinífera: Un análisis con fronteras de producción estocástica. Ciencia e Investigación Agraria 38:321-329.

Mueller, R.A.E., S. Stricker, and D.A. Sumner. 2003. Wine on the Web - Rapid Appraisal of Web Sites by Wineries and Wine Merchants from Australia, California and Germany. Wine Marketing Colloquium. Adelaide, Australia, 26-27 July. p. 10.

Myro, R. 2012. La competitividad exterior de la economía española y sus determinantes. Economistas 130: 39-47.

Oster, S.M. 1999. Modern Competitive Analysis. 3rd ed. Oxford University Press. Nueva York, United State. 434 pp.

Pitts, E., L. O'Connell, and B. McCarthy. 2001. The Competitiveness of the Irish Food Processing Industry. The National Food Centre, Castleknock, Dublin. 28 pp.

Porter, M. 1985. How information gives you competitive advantage. Harvard Business Review 63: 149-150.

Rabobank, 2010. Profits falling in UK wine market trade, Utrecht. Available online at: https:/www. rabobank.com/en/press/news/profits_falling_in_ uk_wine_trade.html (Website accessed: 5 September 2012).

Rebelo J., L.Correira, and J. Caldas. 2007. Adding Value to the Agro-Food Supply Chain in the Future Euromediterranean Space. I Mediterranean Conference of Agro-Food Social Scientists. 103rd EAAE Seminar. Barcelona. p. 19.

Reinert, E. 1995. El concepto «competitividad» y sus predecesores. Una perspectiva nacional de 500 años. Socialismo y Participación 72: 21-40.

Ribeiro, A., A.C. Melo, and R. Vilhena. 2002. Appellation of origin/geographical indication-a 
strategy for the new vitivinicultural world. Paper presented at 27th World Congress on Vine and Wine, Bratislava, Eslovaquia. p. 16.

Roldan, D. 2000. Los indicadores en el contexto de los acuerdos de competitividad de las cadenas productivas. Colección documentos IICA, Serie Competitividad 17. 104 pp.

Roquebert, J., R. Phillips, and P. Westfall. 1996. Markets vs. Management: what drives profitability? Strategic Management Journal 17: 653-664.

Rumelt, R. 1991. How much does industry matter? Strategic Management Journal 12:167-185.

Schumpeter, J.A. 1942. Capitalism, socialism and democracy. Taylor \& France. USA. 437 pp.

Skorpikova. 2002. Factor conditions of the viticulture and wine sector in the EU member states, in the Czech Republic and in the selected candidate countries. Agriculture Econ. 48: 303-310.

Thode, S.F., and J.M. Maskulka. 1998. Place-based marketing strategies, brand equity and vineyard valuation. Journal of Product and Brand Management 7: 379- 399 .

Valenciano, J., and I.M. Román. 2011. La importancia de la Denominación de Origen en la industria vi- tivinícola española. Ciencia Ergo Sum. 18: 135144.

Valentine, N. and G. Krasnik. 2000. SADC trade with the rest of the world: Winning export sectors and revealed comparative advantage ratios. The South African Journal of Economics 68: 267-285.

Van Rooyen, C.J., D. Esterhuizen, and O.T. Doyer. 2000. How competitive is agribusiness in the South African food commodity chain? In: J.H. Trienekens and P.J.P. Zuurbier (eds.). Chain Management in Agribusiness and the Food Industry. Wageningen, The Netherlands: Wageningen Press.

Van Rooyen J., Dirk Esterhuizen, and Lindie Stroebel. 2011. Analyzing the competitive performance of the South African wine industry. International Food and Agribusiness Management Review 4: 179-200.

Vlahović, B., A. Puškarić, and B. Maksimović. 2009. Competitiveness of wine export from the Republic of Serbia. $113^{\text {th }}$ EAAE Seminar. Belgrade, Republic of Serbia. p. 9. 
